\title{
MENINGKATKAN MINAT BELAJAR DAN KREATIVITAS DENGAN MODEL PEMBELAJARAN KOOPERATIF TIPE STUDENT TEAMS ACHIEVEMENT DIVISION (STAD) SISWA
}

\author{
ANNISA FARADIAN PRADEVI, MARIA MELANI IKA SUSANTI, MARIA \\ INDARTI RUSTAMTI \\ Universitas Sanata Dharma \\ e-mail: farannisa37@gmail.com, maria.melani.ika@gmail.com, iin.indarti85@gmail.com
}

\begin{abstract}
ABSTRAK
Penelitian ini bertujuan mengetahui peningkatan minat belajar dan kreativitas dalam pembelajaran matematika pada materi simetri lipat dan simetri putar di kelas III SD Kanisius Kalasan. Penelitian tindakan kelas ini terdiri dari 2 siklus dengan masing-masing dua pertemuan. Data minat belajar dan kreativitas didapat melalui kuesioner dan observasi. Hasil analisis menunjukkan bahwa penerapan model pembelajaran kooperatif berhasil meningkatkan minat belajar dan kreativitas siswa kelas III SD Kanisius Kalasan. Pada siklus I dapat dilihat bahwa peningkatan minat belajar sebesar 11,63\%, kemudian siklus II meningkat sebesar 10,41\%. Peningkatan juga terjadi para kreativitas siswa pada siklus I yaitu 14,86, kemudian ke siklus II 9,96. Minat belajar siswa meningkat dari 55\% ke 77,04\% dan kreativitas siswa meningkat dari 54,31 menjadi 79,13. Dengan demikian, penerapan model pembelajaran tipe STAD dapat meningkatkan minat belajar dan kreativitas siswa kelas III SD Kanisius Kalasan tahun pelajaran 2020/2021.
\end{abstract}

Kata Kunci: minat belajar, kreativitas, kooperatif tipe STAD

\section{PENDAHULUAN}

Sekolah dituntut untuk menciptakan siswa yang dapat berpikir sesuai dengan perkembangan abad 21. Sani (2019: 53) menyatakan bahwa keterampilan belajar dan inovasi pada abad 21 yaitu berpikir kritis, kreativitas, komunikasi dan kolaborasi. Setiap siswa pasti memiliki permasalahan dalam kehidupan sehari-harinya. Dengan memiliki pola berpikir yang kreatif siswa akan mampu menyelesaikan permasalahan tersebut.

Salah satu muatan pelajaran yang dapat diterapkan dalam kehidupan sehari-hari adalah matematika. Matematika merupakan ilmu dasar yang sudah menjadi alat untuk mempelajari ilmu yang lain (Prihandoko, 2006:1). Matematika dapat membantu dalam memahami dan menguasai masalah, sehingga diharapkan siswa mampu untuk mengaplikasikannya hal yang telah dipelajari ke dalam kehidupan sehari-hari. Supaya siswa dapat mempelajari dengan mudah maka guru sebagai pembimbing, perlu menerapkan model pembelajaran yang tepat untuk siswa. Namun karena terkendala pandemi virus covid-19, pembelajaran tidak berjalan secar optimal.

Pada masa pandemi seperti yang terjadi saat ini hampir seluruh lembaga pendidikan menutup kegiatan pembelajaran tatap muka secara langsung dan menyelenggarakan pembelajaran jarak jauh melalui jaringan internet. Hal ini berakibat siswa kurang terkondisi ketika melakukan pembelajaran. Guru kurang optimal dalam memantau proses pembelajaran. Hal ini peneliti temukan ketika melakukan wawancara pada wali kelas IIIA SD Kanisius Kalasan yaitu Ibu A. Wawancara ini peneliti lakukan melalui media sosial WhasApp pada tanggal 9 November 2020 dimana dalam wawancara tersebut terdapat informasi bahwa guru sudah berusaha menggunakan media dengan baik, namun karena pembelajaran bersifat jarak jauh menjadikan siswa sulit untuk memahami materi.

Siswa kelas IIIA SD Kanisius Kalasan mengalami kesulitan dalam memahami materi matematika padahal guru sudah memberikan media berupa video. Menurut Ibu A, mereka dapat dengan mudah memahami materi yang diberikan guru ketika dijelaskan secara tatap muka langsung. Berdasarkan wawancara tersebut, ternyata minat dan kreativitas siswa kelas III SD Kanisius Kalasan dalam mata pelajaran matematika materi simetri lipat dan simetri 
putar masih tergolong kurang. Dilihat dari hasil kuesioner yang dibagikan siswa minat belajar siswa mencapai 55\% dimana persentase tersebut menunjukkan hasil bahwa minat belajar siswa masih tergolong kurang berminat. Slameto (2010: 180) mendefinisikan bahwa minat adalah sesuatu rasa lebih suka dan rasa ketertarikan pada suatu hal atau aktivitas tanpa ada yang mempengaruhi. Minat sangat diperlukan supaya siswa dapat belajar dengan sungguhsungguh. Dalam proses pembelajaran, minat merupakan sebuah awal penggerakan untuk siswa dalam belajar yang dapat digunakan untuk mencapai tujuan yang diingkinkan (Fauziah, Rosnaningsih, Azhar 2017:48).

Dalam pembelajaran jarak jauh ini, siswa diharapkan dapat meningkatkan kreativitasnya. Menurut Munandar dalam Makmur (2016: 2) kreativitas adalah kemampuan untuk membuat kombinasi baru berdasarkan data informasi atau unsur yang ada, berdasarkan data atau informasi yang tersedia, menemukan banyak kemungkinan jawaban terhadap suatu masalah, dimana penekanannya adalah pada kualitas, ketepat gunaan dan keragaman jawaban yang mencerminkan kelancaran, keluwesan dan orisinalitas dalam berfikir serta kemampuan untuk mengelaborasi suatu gagasan. Namun rata-rata kreativitas siswa kelas III SD Kanisius Kalasan hanya mencapai 54,31 yang artinya hasil tersebut menunjukkan bahwa kreativitas siswa tergolong kurang kreatif.

Berkenaan dengan kurangnya minat dan kreativitas siswa kelas III ini mendasar pada kurang tepatnya menerapkan strategi pembelajaran matematika. Guru harus berupaya menciptakan sebuah pembelajaran yang mengutamakan keaktifan siswa. Pembelajaran kooperatif tipe STAD tepat diterapkan untuk pembelajaran di sekolah, khususnya untuk pembelajaran di kelas rendah. STAD merupakan variasi pembelajaran kooperatif dengan membagi siswa menjadi kelompok secara heterogen beranggotakan empat-lima siswa dengan beragam kemampuan yang berbeda (Esminarto dkk, 2016:19).

\section{METODE PENELITIAN}

Penelitian ini menggunakan prosedur penelitian tindakan kelas. Subjek penelitian adalah seluruh siswa kelas III SD Kanisius Kalasan. Penelitian ini dilaksanakan sebanyak 2 siklus dimana masing-masing siklus terdiri atas 2 pertemuan. Tujuan dari penelitian ini untuk meningkatkan minat dan kreativitas siswa dalam pelajaran matematika dengan menggunakan model pembelajaran kooperatif tipe $S T A D$. Penelitian ini menggunakan model penelitian yang dikembangkan oleh Kurt Lewin, yang digambarkan dalam bagan berikut ini.

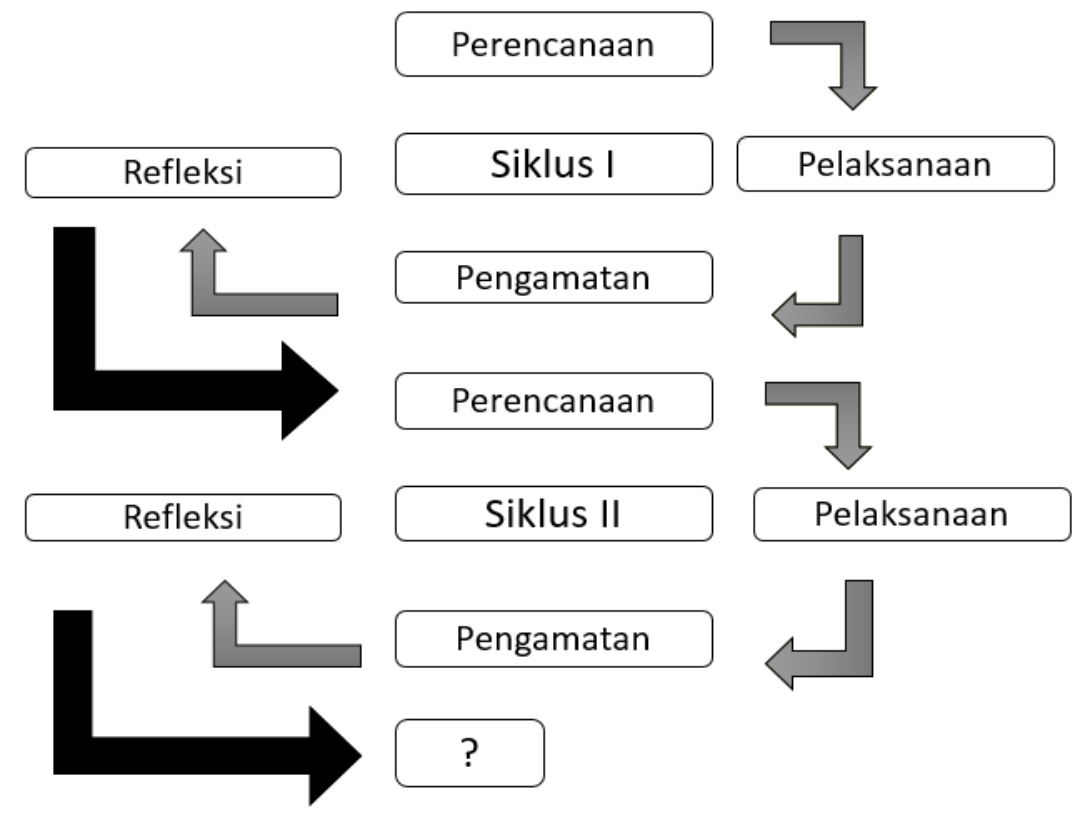

Gambar 1. Bagan penelitian PTK menurut Kurt Lewin 
Dari bagan tersebut dapat dilihat bahwa PTK dimulai dari siklus I hingga siklus II yang terdiri dari empat kegiatan meliputi perencanaan, pelaksanaan, pengamatan dan refleksi.

Pada siklus I akan dimulai dengan tahap perencanaan. Peneliti merancang tindakan yang akan dilakukan berdasarkan masalah yang ada pada siswa kelas III A SD Kanisius Kalasan, yaitu tentang minat belajar dan kreativitas. Kemudian peneliti melaksanakan tindakan berdasarkan perancanaan sebelumnya dengan menerapkan model pembelajaran kooperatif tipe $S T A D$. Setelah data terkumpul, peneliti melakukan pengamatan perubahan kinerja proses belajar. Selanjutnya melakukan refleksi, apabila hasil akhir dari siklus I belum memuaskan maka akan dilanjutkan pada siklus II. Pelaksanaan siklus II merupakan kegiatan penyempurnaan dari siklus I, yaitu memaksimalkan hasilnya. Kegaiatan yang ada pada siklus I dan II sama tetapi perbedaannya terletak pada materi yang diajarkan.

Indikator minat dan kreatif menjadi acuan peneliti untuk mendapatkan data mulai dari pra siklus hingga siklus II melalui wawancara, observasi dan kuesioner. Instrumen yang digunakan peneliti yaitu pedoman wawancara, lembar observasi dan lembar kuesioner. Pedoman wawancara terdiri dari 12 pertanyaan untuk minat dan 12 pertanyaan untuk kreativitas. Lembar observasi terdiri dari 12 pernnyataan untuk minat dan 12 pernyataan untuk kreativitas. Lembar kuesioner terdiri 9 pernyataan positif dan 7 pernyataan negatif. Siswa hanya diminta untuk menjawab "Ya" atau "Tidak" pada pernyataan tersebut.

\section{HASIL DAN PEMBAHASAN \\ Hasil \\ Siklus I}

Pertemuan pertama dilaksanakan pada hari Senin, 15 Maret 2021. Pembelajaran dilaksanakan secara daring melalui Zoom Meeting. Sebelumnya guru menyiapkan link yang digunakan untuk pembelajaran dan dibagikan kepada siswa pada pagi harinya melalui grup Whatsapp kelas III. Pembelajaran dimulai diawali dengan doa dan dilanjutkan dengan menjelaskan materi dan tugas kelompok. Pada pertemuan ini guru mengalami kendala yaitu ada beberapa siswa yang terlihat belum siap mengikuti pembelajaran sehingga ketika dipanggil namanya untuk membacakan teks, siswa harus berulang kali dipanggil.

Pertemuan kedua dilaksanakan pada hari Rabu, 17 Maret 2021. Guru menyiapkan link Zoom Meeting terlebih dahulu dan membagikan pada siswa di pagi hari sebelum memulai pembelajaran. Pertemuan kedua ini siswa lebih siap untuk belajar. Hal ini terlihat ketika siswa masuk sudah memperlihatkan peralatan yang harus disiapkan untuk melakukan praktik. Kendala pertemuan kedua ini adalah guru tidak bisa selalu memantau live chat. Ada beberapa siswa yang mengirim pesan kurang sopan dalam live chat tersebut. Dari hasil analisis data, pada siklus I ini, rata-rata minat siswa mencapai $66,63 \%$ dan rata-rata kreativitas siswa sebanyak 63,17 poin.

\section{Siklus II}

Peremuan pertama dilaksanakan pada hari Jumat, 19 Maret 2021. Pembelajaran masih dilakukan menggunakan Zoom Meeting. Guru mempersiapkan link dan membagi pada siswa di pagi hari sebelum memulai pembelajaran. Guru juga memberikan instruksi peralatan yang harus dipersiapkan pada malam hari sebelum memulai pembelajaran. Pertemuan pertama pada siklus II ini, minat belajar siswa semakin terlihat. Hal ini terbukti ketika melakukan praktik menggunakan media, siswa selalu memperhatikan dan menirukan setiap langkah yang diajarkan oleh guru. Kendala pada pertemuan ini adalah terjadi miskonsepsi pada materi simetri lipat.

Pertemua kedua dilaksanakan pada hari Senin, 22 Maret 2021. Sebelum melaksanakan pembelajaran, terlebih dahulu guru menyiapkan link Zoom Meeting dan membaginya pada siswa di pagi hari sebelum pembelajaran dimulai. Pada pertemuan II ini. Guru memperjelas materi simetri lipat sehingga miskonsepsi yang terjadi pada pertemuan 1 dapat teratasi. Kendala pada pertemuan ini, Zoom Meeting tiba-tiba berhenti sehingga guru dan siswa harus 
masuk kembali untuk meneruskan pembelajaran. Dari hasil analisis data pada siklus II ini rata-rata minat belajar siswa mencapai $77,04 \%$ dan rata-rata kreativitas siswa mencapai 79,13 poin.

\section{Pembahasan}

Minat belajar dalam penelitian ini diukur melalui empat indikator yaitu perasaan senang, ketertarikan siswa, perhatian siswa, dan keterlibatan siswa. Hasil dari analisis data minat belajar siswa pada pelajaran matematika dapat dilihat pada tabel berikut.

Tabel 1. Analsis Data Minat Belajar Siswa

\begin{tabular}{|l|l|l|l|}
\hline No & Siklus & Minat Belajar Siswa & Keterangan \\
\hline 1 & Prasiklus & $55 \%$ & Kurang berminat \\
\hline 2 & Siklus I & $66,63 \%$ & Berminat \\
\hline 3 & Siklus II & $77,04 \%$ & Berminat \\
\hline
\end{tabular}

Berdasarkan tabel tersebut, dapat diketahui persentase minat belajar siswa mulai dari prasiklus hingga siklus II. Pada tahap prasiklus rata-rata minat belajar siswa dalam satu kelas yaitu 55\%, yang mana persentase tersebut menunjukkan bahwa minat belajar siswa kelas III SD Kanisius Kalasan pada pelajaran matematika masuk ke dalam kategori kurang berminat. Pada siklus I siswa menunjukkan perubahan menjadi sebanyak 66,63\%, dan siklus II sebanyak $77,04 \%$. Terdapat peningkatan minat belajar siswa pada setiap tahap penelitian. Persentase kenaikan mulai dari prasiklus hingga siklus II dapat dilihat dalam grafik 1. di bawah ini.

Grafik 1. Analisis Minat Belajar Siswa

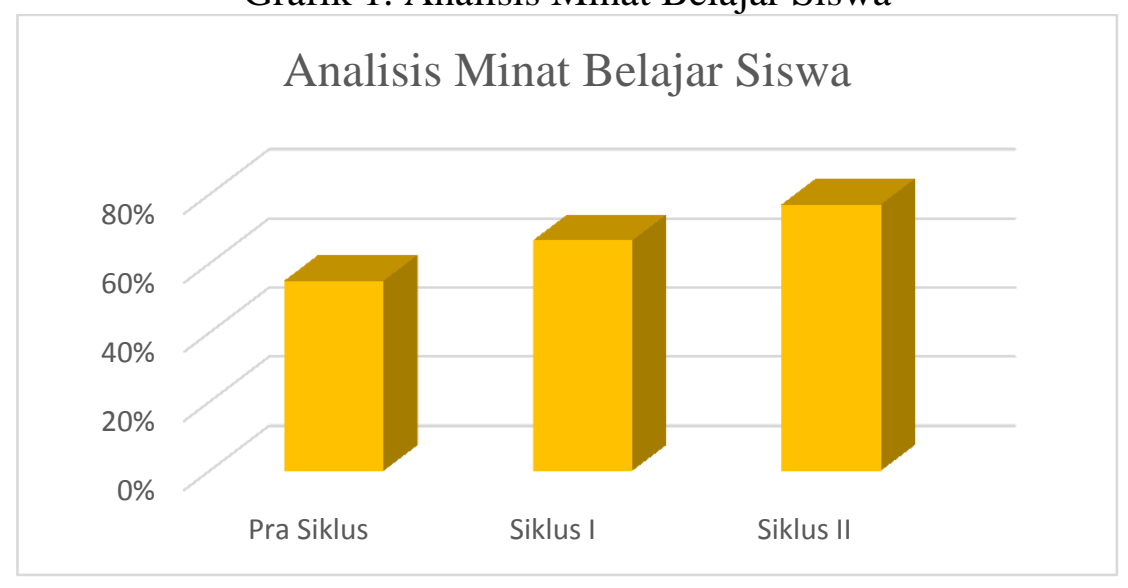

Pada grafik tersebut dapat diketahui perbandingan persentase dan peningkatan minat belajar siswa mulai dari tahap prasiklus sampai dengan siklus II. Pada tahap prasiklus menuju siklus I persentase naik sebanyak 11,63\%, siklus I menuju siklus II naik 10,41\%.

Kreativitas dalam penelitian ini diukur melalui lima indikator yaitu (a) selalu merasa bebas dalam berpikir dan bertindak, (b) mampu menciptakan sesuatu yang baru, (c) mampu mengembangan konsentrasi untuk memacu imajinasi, (d) komitmen terhadap waktu untuk selalu berkarya dari apa yang diketahui, (e) mau mengolah ide. Hasil dari analisis kreativitas siswa dapat dilihat pada tabel berikut.

Tabel 2. Capaian Kreativitas Siswa

\begin{tabular}{|l|l|l|l|}
\hline No & Siklus & Kreativitas Siswa & Keterangan \\
\hline 1 & Prasiklus & 54,31 & Kurang kreatif \\
\hline 2 & Siklus I & 69,17 & Kreatif \\
\hline 3 & Siklus II & 79,13 & Kreatif \\
\hline
\end{tabular}

Berdasarkan tabel tersebut, pada tahap prasiklus rata-rata kreativitas siswa dalam satu kelas masih termasuk dalam kategori kurang kreatif yaitu 54,31. Setelah peneliti memberi tindakan 
pada siklus I terjadi perubahan nilai kreativitas siswa yaitu sebanyak 69,17, dan siklus II sebanyak 79,13. Hal ini menunjukkan bahwa terdapat kenaikan kreativitas pada setiap tahapannya. Kenaikan tersebut dapat dilihat dalam grafik 2. berikut.

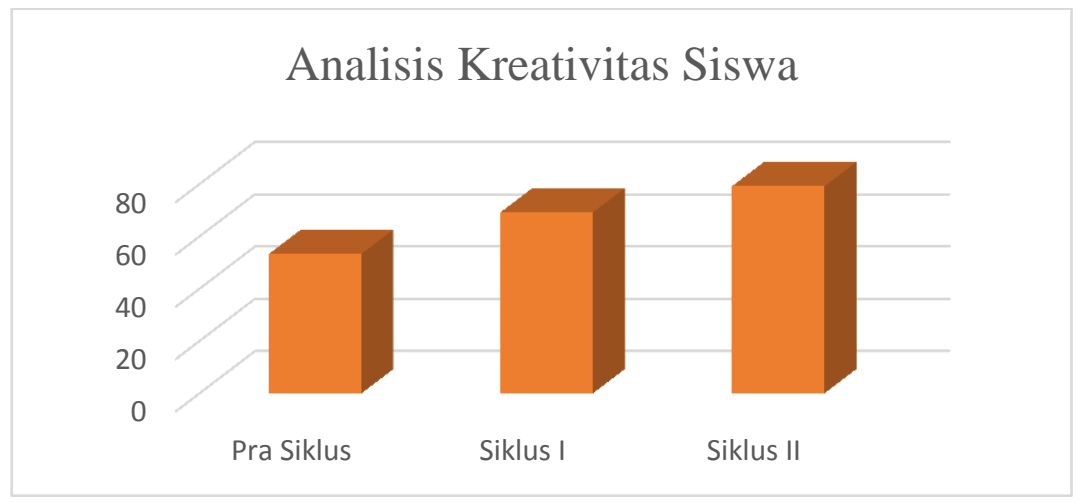

Grafik 2. Analisis Kreativitas Siswa

Pada grafik 2. dapat diketahui perbandingan persentase dan peningkatan minat belajar siswa mulai dari tahap prasiklus sampai dengan siklus II. Pada tahap prasiklus menuju siklus I naik sebanyak 14,86 poin, siklus I menuju sklus II naik 9,96 poin.

Dari tabel dan grafik di atas dapat dilihat bahwa minat dan kreativitas siswa pada tahap prasiklus masih tergolong rendah. Berdasarkan dari rata-rata minat dan kreativitas yang peneliti dapatkan, peneliti menerapkan model pembelajaran kooperatif tipe STAD pada pembelajaran matematika pada materi simetri lipat dan simetri putar, sehingga hasilnya mengalami peningkatan pada siklus I dan siklus II.

Pembelajaran yang dilakukan dalam jaringan ini cukup menantang apabila membagi tugas secara berkelompok, namun siswa-siswi kelas III SD Kanisius Kalasan begitu antusias untuk mengerjakan tugas mereka. Orang tua wali juga antusias membantu putra-putrinya membentuk kelompok ke dalam grup WhatsApp, sehingga mereka dapat berdiskusi kelompok di dalamnya. Hal tersebut menunjukkan bahwa minat belajar peserta didik mulai nampak. Selain meningkatkan minat siswa, penggunaan model pembelajaran kooperatif tipe STAD juga meningkatkan hasil krativitas siswa yang dapat dilihat pada tabel 2. Model pembelajaran ini dapat mengajak siswa untuk menghasilkan karya yang kreatif. Dalam pembelajaran, kreativitas sangat berperan penting. Seperti yang dikatakan oleh Sayoga (2017: 76) bahwa siswa yang kreatif unggul dalam belajar, memiliki rangsangan semangat dalam belajar, mudah berinteraksi dengan siswa lain, mengerti bagaimana memecahkan suatu permasalahan dan meningkatkan peran siswa dalam pergaulan di sekolahnya.

Keseluruhan penelitian ini menunjukkan adanya peningkatan minat dan kreativitas belajar siswa pada setiap tahapannya menggunakan model pembelajaran kooperatif tipe $S T A D$. Hasil ini sejalan dengan beberapa peneliti terdahulu yang berujung pada kesimpulan bahwa penggunaan model pembelajaran kooperatif tipe STAD berhasil meningkatkan kreativitas dan hasil belajar muatan IPA (Setyowati, Harjono, Airlanda, 2018). Kemudian penelitian yang dilakukan oleh Laa, Winata, Meilani (2017) juga mendapatkan kesimpulan bahwa penggunaan model pembelajaran STAD efektif menigkatkan minat belajar siswa.

Penelitian ini tentu telah dilaksanakan sebaik mungkin, namun masih memiliki kekurangan yaitu dalam pembelajaran jarak jauh atau dalam jaringan, penjelasan materi menjadi kurang maksimal. Selain penjelasan materi, proses pengambilan data juga kurang maksimal karena guru tidak dapat memantau secara langsung proses pengerjaan tugas yang dilakukan secara berkelompok.

\section{KESIMPULAN}

Berdasarkan hasil penelitian dapat disimpulkan bahwa penerapan model pembelajaran kooperatif tipe STAD dapat meningkatkan minat dan kreativitas siswa. Hal tersebut terlihat 
dari hasil analisis dan pembahasan yang dijabarkan dalam penelitian ini. Minat belajar siswa terdapat peningkatan mulai dari prasiklus hingga siklus II. Rata-rata minat belajar siswa mulai dari $55 \%$ menjadi $66,63 \%$. Rata-rata kreativitas siswa juga mengalami peningkatan yaitu mulai dari 54,31 menjadi 79,13.

\section{DAFTAR PUSTAKA}

Esminarto, Sukowati, Suryowati, \& Anam. (2016). Implementasi Model STAD Dalam Meningkatkan Hasil. Jurnal Riset dan Konseptual Volume 1 Nomor 1, 16.

Fauziah, Rosnaningsih, \& Azhar. (2017). Hubungan Antara Motivasi Belajar dengan Minat. Jurnal JPSD Vol. 4 No. 2 , 48.

Laa, n., Winata, H., \& Meilani, I. R. (2017). Pengaruh model pembelajaran kooperatif tipe student teams achievement division terhadap minat belajar siswa. Jurnal Pendidikan Manajemen Perkantoran, 139-148.

Makmur, A. (2016). Upaya Meningkatkan Kreativitas dan Hasil Belajar. Jurnal EduTech Vol. 2 No. $2,2$.

Prihandoko, A. C. (2006). Pemahaman dan penyajian konsep matematika secara benar dan menarik. Jakarta: Departemen Pendidikan Nasional.

Sani, R.A. (2019). Pembelajaran berbasis HOTS (High Order Thinking Skills) Tangerang: Tira Smart.

Sayoga, S. (2017). Peningkatan Kreativitas dan Hasil Belajar MDDE melalui Model Pembelajaran STAD . Varia Pendidikan, 75-86.

Setyowati, W. T., Harjono, M., \& Airlanda, G. S. (2018). Penggunaan Model Student Teams Achievement Division (STAD) Berbantu Media Gambar dalam Upaya Meningkatkan Kreativitas dan Hasil Belajar Muatan IPA Tema 7 "Peristiwa Dalam Kehidupan" Siswa. Jurnal Ilmiah Pendidikan dan Pembelajaran, 167-173.

Slameto. (2010). Belajar dan faktor-faktor yang mempengaruhinya. Jakarta: Rineka Cipta. 